\title{
Perbandingan Area Inefsiensi Antara Nilai Pajak dan Zakat
}

\section{Comparison of inefficiency areas between tax and zakat value}

\section{Muthia Faridatunnisa}

Program Studi D4 Keuangan Syariah, Politeknik Negeri Bandung

E-mail: muthiafaridatunnisa.ksy15@polban.ac.id

\section{Mochamad Edman Syarief}

Jurusan Akuntansi, Politeknik Negeri Bandung

E-mail: edman.syarief@polban.ac.id

\section{Endang Hatma Juniwati}

Jurusan Akuntansi, Politeknik Negeri Bandung

E-mail: endang.hatma@polban.ac.id

\begin{abstract}
Tax policies set by the government can cause inefficiencies. Zakat policy is expected to minimize these inefficiencies. This research will try to compare how much inefficiency area caused by the value of tax and zakat. The data used is secondary data in the form of production from five business sectors found in Gross Domestic Product based on 2010 constant prices for the 2014-2018 period from the Central Bureau of Statistics. In this study quantitative calculations were carried out to determine the tax value, zakat value, and the area of triangle inefficiency, then after obtaining the results it would be compared to the magnitude of the triangle of inefficiency based on the value of tax and rakat. Different tests were carried out using SPSS to see whether the difference was significant or not. From the results of independent sample t-test, it is known that there are significant differences between the areas of inefficiency of the tax value and the value of zakat. This states that zakat produces inefficiency areas smaller than taxes.
\end{abstract}

Keywords: taxes, zakat, inefficiency

\section{Pendahuluan}

Redistribusi pendapatan merupakan kebijakan pemerintah dalam hal pemerataan pendapatan dengan cara penghimpunan dana dari publik (baik pajak maupun non-pajak) yang diperuntukkan untuk kepentingan masyarakat. Pajak merupakan alat redistribusi pendapatan utama di Indonesia, pajak tersebut dibebankan kepada pihak yang memiliki kewajiban membayar, sedangkan dalam Islam ada kewajiban berupa zakat yang merupakan alat redistribusi dimana secara material zakat juga dapat menciptakan pemerataan pendapatan, kesejahteraan, dan pertumbuhan ekonomi bagi orang-orang miskin (Iman dkk., 2018).

Pemungutan pajak sebagai pendapatan negara adalah hal positif, namun dalam kenyataannya jika kita analisis kembali, tenyata penetapan pajak dapat meningkatkan harga dan mengurangi output, produsen menaikkan harga karena ada pajak yang harus dibayar kemudian diatur sedemikian rupa sehingga pengenaannya dibebankan secara tidak langsung kepada konsumen, dengan harga yang tinggi maka permintaan barang atau jasa pun akan semakin sedikit. Produsen memperoleh keuntungan lebih sedikit dari barang tersebut karena pajak, sedangkan konsumen harus membayar harga lebih tinggi. Pajak dinilai kurang efisien karena akan menaikkan biaya produksi dan secara otomatis akan manaikkan harga (Widiyanti, 2016). 
Berdasarkan penelitian sebelumnya yang dikemukakan oleh Dwi Retno Widiyanti tahun 2016 yang berjudul Partial Equilibrium Analysis of Zakat menjelaskan bahwa mekanisme zakat tidak akan menyebabkan inefisiensi dalam ekonomi, karena pergeseran kurva permintaan dan penawaran menghasilkan jumlah kuantitas produk yang lebih besar dalam tingkat harga yang sama, sedangkan mekanisme perpajakan dan subsidi akan menyebabkan inefisiensi dalam ekonomi, karena pergeseran kurva penawaran dan permintaan menghasilkan jumlah kuantitas produk yang lebih kecil pada tingkat harga yang lebih tinggi. Hal ini sejalan dengan upaya memaksimalkan profit yang berarti memaksimalkan producer surplus dan sekaligus memaksimalkan zakat yang harus dibayar (Karim, 2007). Zakat tidak akan menimbulkan deadweight loss dalam perekonomian dimana nilai 2,5\% merupakan besaran yang tidak akan menimbulkan distorsi di dalam perekonomian (Al Arif M. R., 2013). Berdasarkan penelitian dan teori di atas dapat disimpulkan bahwa skema pembayaran dan penyaluran zakat merupakan cara efektif dan efisien dalam hal redistribusi pendapatan.

Penelitian ini mencoba untuk membandingkan area inefisiensi antara nilai pajak dan nilai zakat, maka dari itu penelitian ini bertujuan untuk melakukan simulasi perhitungan dengan membandingkan antara daerah inefisiensi nilai pajak dan nilai zakat sehingga akan ada pembuktian dari sisi akademik bahwa zakat tidak akan menimbulkan inefisiensi yang besar seperti halnya yang ditimbulkan oleh pajak.

\section{Kajian Pustaka}

Sudah diketahui dalam analisis ekonomi bahwa pajak yang ditambahkan pada sebuah kurva keseimbangan permintaan dan penawaran akan menghasilkan daerah deadweight loss. Deadweight loss adalah pengurangan area surplus konsumen dan surplus produsen apabila produksi dibatasi sehingga lebih rendah dari efisiensi optimum atau bisa diartikan juga hilangnya efisiensi ekonomi untuk konsumen maupun produsen karena efisiensi alokasi sumber daya tidak terpenuhi (Galang, 2017). Daerah ini merupakan daerah inefisiensi, disebut demikian karena daerah tersebut tidak dimanfaatkan oleh pihak manapun, baik itu konsumen, produsen, maupun pemerintah. Jika digambarkan dalam bentuk kurva, maka akan menghasilkan gambar sebagai berikut :

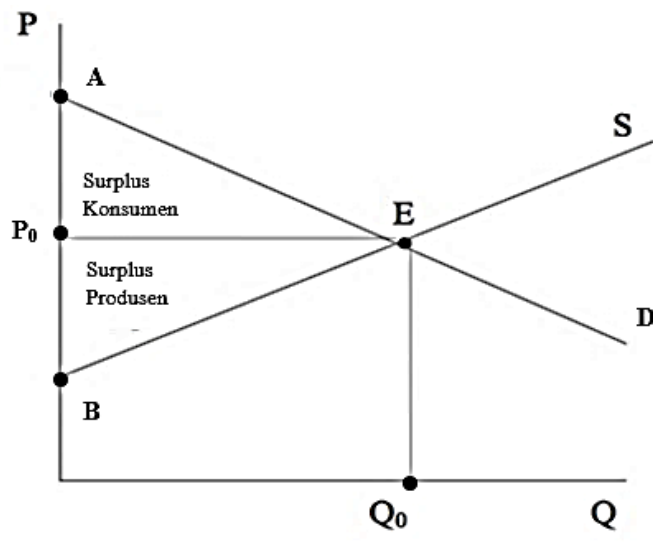

Gambar 1. Kurva Keseimbangan sebelum Pajak

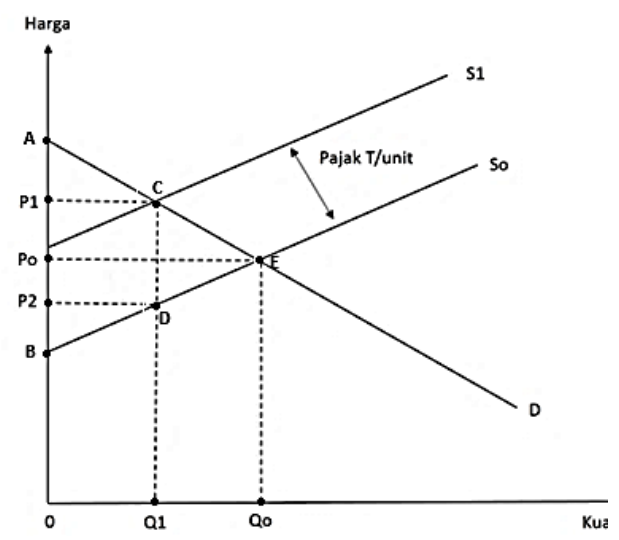

Gambar 2. Kurva Keseimbangan setelah Pajak

Dari gambar di atas dijelaskan bahwa surplus konsumen merupakan total bidang yang berada di bawah kurva demand (D) dan di atas garis harga yang disepakati $\left(\mathrm{P}_{0}\right)$, daerah tersebut berbentuk segitiga $\mathrm{AEP}_{0}$. Titik A merupakan harga tertinggi yang dapat dibayar oleh konsumen yang memiliki ketersediaan membayar lebih tinggi daripada harga yang disepakati, karena dapat diketahui bahwa setiap konsumen memiliki kemampuan membayar yang berbeda dari segi pendapatan atau kepemilikan. Selisih antara titik A dengan $\mathrm{P}_{0}$ merupakan surplus konsumen. Sedangkan surplus 
produsen merupakan total bidang yang berada di atas kurva supply (S) dan di bawah garis harga yang disepakati $\left(\mathrm{P}_{0}\right)$, daerah tersebut berbentuk segitiga $\mathrm{BEP}_{0}$. Titik $\mathrm{B}$ merupakan biaya produksi terendah yang dikeluarkan produsen dalam memproduksi barang atau jasa untuk dijual atau ditawarkan kepada konsumen. Karena, dapat diketahui bahwa produsen yang memiliki biaya paling rendah dalam memproduksi akan mendapatkan keuntungan atau revenue yang paling tinggi. Selisih antara titik $\mathrm{B}$ dengan $\mathrm{P}_{0}$ merupakan surplus produsen.

Ketika pajak ditetapkan, maka harga yang akan ditawarkan pada konsumen akan naik dari $\mathrm{P}_{0}$ ke $\mathrm{P}_{1}$, kemudian kuantitas barang pun akan berkurang dari $\mathrm{Q}_{0}$ ke $\mathrm{Q}_{1}$. Hal ini berdampak pada surplus konsumen akan berkurang sebesar daerah $\mathrm{P}_{1} \mathrm{P}_{0} \mathrm{EC}$, sehingga daerah surplus konsumen menjadi $\mathrm{AP}_{1} \mathrm{C}$. Sedangkan surplus produsen akan berkurang sebesar daerah $\mathrm{P}_{0} \mathrm{P}_{2} \mathrm{DE}$, sehingga daerah surplus produsen menjadi $\mathrm{BP}_{2} \mathrm{D}$. Seharusnya beban pajak yang dibayar produsen dan konsumen menjadi penerimaan bagi pemerintah, namun dengan adanya segitiga DCE yang merupakan deadweight loss maka pemerintah tidak menerima sepenuhnya. DWL mengurangi porsi penerimaan pemerintah, sehingga yang diterima sebesar area $\mathrm{P}_{1} \mathrm{CDP}_{2}$. Kurva dalam gambar 2.2 menjelaskan bahwa pajak dapat menimbulkan daerah inefisiensi dimana semakin besar tarif pajak semakin besar pula daerah inefisiensi tersebut, seperti pernyataan Musonnif dan Asiyah (2012) bahwa pajak yang terlalu tinggi (excessive tax) dapat mengakibatkan terjadinya efficiency loss atau deadweight loss. Oleh karena itu, deadweigtht loss ini penting untuk ditelaah karena daerah inefisiensi tersebut merupakan daerah yang sangat krusial, dimana distorsi ekonomi (ketidaksempurnaan pasar) menyebabkan inefisiensi yaitu ditandai dengan terdapatnya bagian yang tidak dimanfaatkan oleh pihak manapun, hal ini sesuai dengan konten materi yang pernah dimuat dalam Majalah Indonesian Tax Review tahun 2013.

Penelitian Dwi Retno Widiyanti (2016) berfokus pada bagaimana konsep redistribusi zakat menguntungkan dan menegaskan keuntungannya untuk peningkatan efisiensi ekonomi dalam mencapai keseimbangan dengan membandingkan kurva pajak dan zakat dengan melakukan simulasi pada persediaan dan permintaan produk dalam mekanisme keseimbangan parsial. Penelitian terebut sesuai dengan dengan pernyataan Benkler dalam Beik (2009) yang merupakan profesor di sekolah hukum Universitas Yale AS, yaitu konsep berbagi merupakan modal yang sangat penting untuk meningkatkan produksi dalam perekonomian, perusahaan yang menerapkan konsep ini akan lebih efisien dibandingkan dengan perusahaan yang tidak menerapkannya. Hal ini diperkuat oleh penelitian yang dilakukan oleh Cahyono dan Putri (2012) yang menyatakan bahwa perhitungan $\mathrm{PPh}$ badan dengan menerapkan zakat sebagai perencanaan pajak hasilnya lebih efisien dibandingkan tidak menerapkan zakat.

Di Indonesia, pengetahuan mengenai zakat perusahaan atau badan masih sebatas zakat fitrah dan zakat pribadi belum sampai pada zakat kekayaan, sehingga tingkat kesadaran membayar zakat masih sangat minim karena zakat perusahaan atau badan dianggap bukanlah suatu kewajiban yang memaksa seperti pajak. Keadaan ini sesuai dengan penelitian yang dilakukan oleh Reza (2012), beliau meneliti tiga perusahaan milik pengusaha Arab dimana perusahaan pertama menyisihkan 2,5\% dari total ekuitas selama satu tahun kemudian sisanya dibagikan sebagai deviden karena pihak perusahaan percaya pembayaran tersebut akan mengundang keberkahan baik bagi usahanya maupun kebaikan di akhirat, perusahaan kedua menyamakan antara pajak dengan zakat karena jika perusahaan tersebut membayar zakat maka perusahaan akan menjadi rugi karena melakukan dua kali pembayaran sehingga keuntungannya berkurang, dan perusahaan ketiga menyamakan pembayaran zakat dengan CSR karena peruntukkannya juga untuk umat misalnya pembangunan masjid, walaupun demikian zakat tetap memiliki nilai yang lebih tinggi karena jelas ketentuannya.

Maka kerangka pemikiran dalam penelitian ini yaitu baik pajak maupun zakat yang menghasilkan area inefisiensi atau deadweight loss lebih kecil bisa dikatakan lebih efisien dari yang dibandingkannya, sehingga hipotesis yang dibangun yaitu $\left(\mathrm{H}_{1}\right)$ terdapat perbedaan yang signifikan 
antara daerah inefisensi nilai pajak dan nilai zakat.

\section{Metode Penelitian}

Jenis penelitian yang dilakukan dalam penelitian ini berdasarkan tingkat eksplanasinya atau penjelasannya termasuk kedalam penelitian komparatif, yaitu suatu penelitian yang bersifat membandingkan. Metode komparatif sering dilakukan pada jenis penelitian yang mengarah pada perbedaan variabel dalam suatu aspek yang diteliti. Berikut ini merupakan rancangan penelitian yang dilakukan diantaranya adalah sebagai berikut :

1. Menghitung secara kuantitatif mengenai nilai pajak, yaitu dengan cara mencari harga produsen dan kuantitas keseimbangan berdasarkan data yang ada.

2. Menghitung secara kuantitatif mengenai nilai zakat berdasarkan harga produsen dan kuantitas keseimbangan.

3. Menghitung segitiga inefisiensi dengan cara menghitung luas daerah segitiga.

4. Melakukan uji beda untuk melihat apakah perbedaan tersebut signifikan atau tidak. Uji beda dilakukan dengan menggunakan SPSS. Jika data terdistribusi normal akan digunakan uji beda rata-rata dua sampel independen, namun jika data tidak tersebar normal maka akan dilakukan uji beda non-parametrik dengan menggunakan Mann-Whitney U-Test.

Objek penelitian berisi tentang variabel-variabel penelitian juga karakteristik atau unsur-unsur yang akan diteliti, populasi penelitian, sampel penelitian, unit sampel penelitian dan tempat penelitian, dalam bagian ini termasuk cara untuk penarikan sampel (Suryana, 2010). Objek penelitian dalam penelitian ini adalah nilai pajak dan nilai zakat. Dalam penelitian ini digunakan data kuantitatif yang menurut sumbernya termasuk data sekunder. Data yang diambil berupa hasil produksi dari setiap sektor yang terdapat dalam Produk Domestik Bruto menurut lapangan usaha berdasarkan harga konstan tahun 2014 sampai 2018 dari situs Badan Pusat Statistik. Sumber penunjang lainnya berupa data pajak dikurang subsidi yang didapat dari data PDB, Indeks Harga Konsumen tahun 2014 sampai 2018, Indeks Harga Produsen tahun 2014 sampai 2018, dan Survei Biaya Hidup tahun 2012. Semua data penunjang diambil dari situs Badan Pusat Statistik.

\section{Hasil dan Pembahasan}

\subsection{Proses Perhitungan}

Sebelum membahas pembuktian dari hipotesis penelitian, maka perlu dilakukan beberapa tahap perhitungan untuk dapat menganalisis perbedaan antara satu variabel dengan variabel lainnya, berikut beberapa langkah yang harus dilakukan, diantaranya yaitu :

1) Menghitung secara kuantitatif besarnya nilai pajak dan nilai zakat.

2) Menghitung besarnya daerah inefisiensi.

Setelah melakukan perhitungan dan diketahui besarnya daerah inefisiensi, maka hasilnya dibandingkan dengan uji beda, untuk melihat apakah perbedaan tersebut signifikan atau tidak, supaya dapat menjawab rumusan masalah dan hipotesis yang telah dibuat.

\section{Perhitungan Nilai Pajak dan Nilai Zakat}

Untuk menghitung besarnya area inefisiensi, maka terlebih dahulu hal yang dilakukan adalah menghitung nilai pajak dan nilai zakat, masing-masing hasilnya didapatkan dari langkah-langkah sebagai berikut ini:

\section{Nilai Pajak}

Langkah-langkah perhitungan nilai pajak adalah sebagai berikut : 
1) Mengelompokkan lapangan usaha yang akan dilakukan penelitiannya, pemilihan lapangan usaha diputuskan dengan cara memilih lapangan usaha yang memiliki kesamaan indikator dengan data Indeks Harga Konsumen dan Indeks Harga Produsen, sehingga data dapat berpasangan. Hal ini dilakukan supaya memberikan kemudahan bagi peneliti ketika melakukan simulasi perhitungan daerah inefisiensi. Berikut lima lapangan usaha yang digunakan:

a. Pertanian, kehutanan, dan perikanan

b. Industri pengolahan

c. Listrik, gas, dan air

d. Transportasi dan pergudangan

e. Penyediaan akomodasi, makanan, dan minuman

2) Karena yang digunakan hanya lima lapangan usaha, maka tahap pertama yang dilakukan yaitu menghitung nilai tambah untuk lima lapangan usaha tersebut. Nilai tambah lima lapangan usaha didapatkan dari penjumlahan produksi dari Pertanian, kehutanan, dan perikanan + Industri pengolahan + Listrik, gas, dan air + Transportasi dan pergudangan + Penyediaan akomodasi, makanan, dan minuman.

Nilai tambah sendiri mempunyai pengertian yaitu salah satu komponen pembentuk Produk Domestik Bruto (PDB) yang menggambarkan selisih antara nilai produksi (output) dan biaya antara (biaya yang habis dipakai selama proses produksi) dari suatu produk, baik barang maupun jasa.

3) Setelah itu menghitung besar pajak dikurangi subsidi untuk lima lapangan usaha, yaitu dengan cara nilai tambah lima lapangan usaha dibagi dengan nilai tambah keseluruhan lalu dikalikan dengan pajak dikurang subsidi keseluruhan. Bila dituangkan dalam rumus adalah sebagai berikut :

\section{nilai tambah lima lapangan usaha nilai tambah keseluruhan $x$ pajak dikurang subsidi keseluruhan}

Untuk lebih memperjelas, maka rumus ini akan diberikan contoh perhitungan pada satu lapangan usaha yaitu pertanian, kehutanan, dan perikanan tahun 2014:

Diketahui : Nilai tambah untuk lima lapangan usaha untuk tahun 2014 adalah sebagai berikut:

Tabel 1. Nilai Tambah Lima Lapangan Usaha 2014

\begin{tabular}{|c|l|c|}
\hline No. & \multicolumn{1}{|c|}{ Sektor Lapangan Usaha } & Produksi \\
\hline l. & Produksi pertanian, kehutanan, dan perikanan & 1.129 .053 \\
\hline 2. & Produksi industri pengolahan & 1.854 .257 \\
\hline 3. & $\begin{array}{l}\text { Produksi pengadaan listrik, gas, air, pengelolaan } \\
\text { sampah, limbah, dan daur ulang }\end{array}$ & 94.334 \\
\hline 4. & Produksi Transportasi dan pergudangan & 326.933 \\
\hline 5. & Penyediaan akomodasi, makanan, dan minuman & 257.816 \\
\hline \hline \multicolumn{2}{|c|}{ Nilai tambah lima lapangan usaha } & $\mathbf{3 . 6 6 2 . 3 9 2}$ \\
\hline
\end{tabular}

Nilai tambah keseluruhan pada tahun 2014 adalah 8.351 .369

Pajak dikurang subsidi keseluruhan tahun 2014 adalah 213.498

Jawab : Pajak lima lapangan usaha $=\frac{3.662 .392}{8.351 .369} \times 213.498=93.627$

Maka PDB untuk lima lapangan usaha adalah nilai tambah lima lapangan usaha ditambah pajak dikurang subsidi lima lapangan usaha yaitu 3.756.019

4) Kemudian, menghitung nilai pajak perlapangan usaha. Nilai pajak didapatkan dari produksi dibagi nilai tambah lima lapangan usaha lalu dikalikan dengan pajak dikurang subsidi lima lapangan usaha. Bila dituangkan dalam rumus adalah sebagai berikut : 


\section{produksi}

Nilai tambah lima lapangan usaha $x$ Pajak lima lapangan usaha

Contoh perhitungan nilai pajak pertanian, kehutanan, dan perikanan tahun 2014:

Diketahui : Produksi untuk pertanian, kehutanan, dan perikanan tahun 2014 adalah 1.129.053

Nilai tambah lima lapangan usaha adalah 3.662.392

Pajak lima lapangan usaha adalah 93.627

Jawab $\quad$ : Nilai pajak $=\frac{1.129 .053}{3.662 .392} \times 93.627=28.864$

Contoh perhitungan di atas berlaku juga untuk sektor industri pengolahan; listrik, gas, dan air; transportasi dan pergudangan; penyediaan akomodasi, makanan, dan minuman. Berikut ini merupakan hasil perhitungan dari nilai pajak untuk setiap sektor lapangan usaha, nilai tambah, pajak dikurang subsidi, dan PDB untuk lima sektor lapangan usaha tahun 2014 sampai 2018 :

Tabel 2. Nilai Pajak

\begin{tabular}{|c|c|c|c|c|c|c|c|c|c|c|}
\hline \multirow{3}{*}{$\begin{array}{l}\text { PDB Lapangan Usaha (Seri } \\
\text { 2010) }\end{array}$} & \multicolumn{10}{|c|}{$\begin{array}{c}\text { [Seri 2010] PDB Seri } 2010 \text { (Milyar Rupiah) } \\
\text { Harga Konstan } 2010\end{array}$} \\
\hline & \multicolumn{2}{|c|}{2014} & \multicolumn{2}{|c|}{2015} & \multicolumn{2}{|c|}{2016} & \multicolumn{2}{|c|}{2017} & \multicolumn{2}{|c|}{2018} \\
\hline & Nilai Pajak & Produksi & Nilai Pajak & Produksi & $\begin{array}{l}\text { Nilai } \\
\text { Pajak }\end{array}$ & Produksi & $\begin{array}{l}\text { Nilai } \\
\text { Pajak }\end{array}$ & Produksi & $\begin{array}{l}\text { Nilai } \\
\text { Pajak }\end{array}$ & Produksi \\
\hline A. Pertanian, Kehutanan, dan & 28.864 & 1.129 .053 & 38.105 & 1.171 .446 & 44.845 & 1.210 .956 & 50.391 & 1.257 .876 & 55.166 & 1.307 .026 \\
\hline B. Industri Pengolahan & 47.403 & 1.854 .257 & 62.927 & 1.934 .533 & 74.691 & 2.016 .877 & 84.266 & 2.103 .466 & 92.571 & 2.193 .266 \\
\hline C. Listrik, gas, air & 2.412 & 94.334 & 3.097 & 95.202 & 3.986 & 107.645 & 4.082 & 101.884 & 4.876 & 115.530 \\
\hline $\begin{array}{l}\text { D. Transportasi dan Pergudan } \\
\text { E. Penyediaan Akomodasi }\end{array}$ & 8.358 & 326.933 & 11.348 & 348.856 & 13.882 & 374.843 & 16.292 & 406.679 & 18.368 & 435.185 \\
\hline dan Makan Minum & 6.591 & 257.816 & 8.748 & 268.922 & 10.474 & 282.823 & 11.941 & 298.079 & 13.293 & 314.955 \\
\hline Nilai Tambah & & 3.662 .392 & & 3.818.959 & & 3.993 .144 & & 4.167.984 & & 4.365.963 \\
\hline Pajak dikurang Subsidi & & 93.627 & & 124.225 & & 147.878 & & 166.971 & & 184.275 \\
\hline PDB & & 3.756 .019 & & 3.943 .184 & & 4.141 .022 & & 4.334 .956 & & 4.550 .238 \\
\hline
\end{tabular}

Sumber : Data Sekunder Diolah Kembali

\section{Nilai Zakat}

Langkah-langkah perhitungan nilai zakat adalah sebagai berikut :

1) Perhitungan nilai zakat didapat dari :

$$
\text { Nilai zakat }=(\text { Pe } \times \text { Qe })-(P p \times Q e)
$$

2) Perhitungan ini bisa dilakukan setelah mengetahui besar harga produsen ( $\mathrm{Pp}$ ) yang dihasilkan dari :

$$
\mathrm{Pp}=-\left(\frac{\text { Nilai pajak }}{\mathrm{Qe}}\right)+\mathrm{Pe}
$$

Diasumsikan bahwa harga produsen merupakan harga awal yang ditawarkan dan belum ditambah oleh besarnya pajak atau zakat, sehingga harga keseimbangan zakat bisa didapat dengan melakukan penambahan dari harga produsen $(\mathrm{Pp})$ yaitu ditambah 0,025 atau 2,5\%.

Kondisi kuantitas keseimbangan masih sama dengan kuantitas keseimbangan pada saat perhitungan besarnya nilai pajak. Maka nilai zakat bisa didapatkan dari harga keseimbangan (Pe) dikali kuantitas keseimbangan (Qe) dikurangi dengan harga produsen (Pp) dikali kuantitas keseimbangan (Qe).

\section{Perhitungan Area Inefisiensi}




\section{Area Inefisiensi Pajak}

Langkah-langkah perhitungan area inefisiensi pajak yaitu:

1) Untuk menghitung area inefisiensi pajak, terlebih dahulu harus mengetahui besarnya harga keseimbangan (Pe). Harga keseimbangan bisa didapatkan dari Indeks Harga Konsumen tahun bersangkutan dibagi dengan Indeks Harga Konsumen tahun dasar dikali dengan Survei Biaya Hidup tahun 2012.

IHK $2012=100$ adalah IHK yang digunakan dalam perhitungan ini. Indeks Harga Konsumen merupakan hasil dari perhitungan menggunakan formula Laspeyres. Rumus Laspeyres adalah sebagai berikut :

$$
\mathrm{I}_{01}=\frac{\sum_{i=1}^{n} p i 1 q i 0}{\sum_{i=1}^{n} p i 0 q i 0}=\mathrm{L}_{01}
$$

Indeks Harga Konsumen bisa digunakan salah satunya untuk mengetahui perubahan harga dari sekelompok barang dan jasa yang pada umumnya dikonsumsi masyarakat. Survei Biaya Hidup digunakan sebagai pengali dalam perhitungan, karena menurut sumber dari Badan Pusat Statistik, harga yang digunakan untuk menghitung IHK bersumber dari Survei Harga Konsumen (SHK) dan variabel penyusun indikator ini dilengkapi dari Survei Biaya Hidup (SBH). Sedangkan data yang ditemukan berupa SBH tahun 2012. Maka dari itu, tahun 2012 menjadi tahun dasar perhitungan. Adapun alasan mengapa tahun terakhir adalah 2012, karena Survei Biaya Hidup dilakukan setiap lima sampai sepuluh tahun sekali.

Bila dituangkan dalam rumus harga keseimbangan (Pe) adalah sebagai berikut:

$$
\mathrm{Pe}=\frac{\mathrm{IHK} \text { tahun bersangkutan }}{\mathrm{IHK} \text { tahun dasar }} \times \mathrm{SBH}
$$

Contoh perhitungan Pe pertanian, kehutanan, dan perikanan tahun 2014 :

Diketahui : IHK tahun $2014=113,22$

IHK tahun $2012=132,90$

SBH tahun $2012=18,85$

Jawab $\quad: \mathrm{Pe}=\frac{113,22}{132,90} \times 18,85=16,06$

Asumsi yang digunakan untuk titik Pe yaitu harga yang disepakati di pasar sudah termasuk pajak.

2) Setelah itu menghitung besarnya kuantitas keseimbangan (Qe), dengan cara membagi produksi dengan harga keseimbangan. Bila dituangkan dalam rumus adalah sebagai berikut:

Contoh perhitungan Qe pertanian, kehutanan, dan perikanan tahun 2014 :

$$
\mathrm{Qe}=\frac{\text { Produksi }}{\mathrm{Pe}}
$$

Diketahui : Produksi pertanian, kehutanan, dan perikanan tahun 2014 adalah 1.129.053

Pe (harga keseimbangan) yaitu 16,06

Jawab $\quad: Q e=\frac{1.129 .053}{16,06}=70.308$

3) Asumsi yang digunakan dalam perhitungan ini yaitu, Pe dan Qe merupakan titik equilibrium atau keseimbangan yang dapat dibeli oleh konsumen dan ditawarkan oleh produsen dengan harga yang disepakati.

4) Kemudian langkah selanjutnya yaitu menghitung kenaikan harga dalam IHP. Walaupun dalam perhitungan ini IHP tidak begitu dilihat hasilnya, namun setidaknya hasilnya bisa menggambarkan berapa kenaikan harga produsen. Hal ini dikarenakan sumber data harga yang digunakan dalam IHP yaitu Survei Harga Produsen (SHP) tidak tersedia dan tahun dasar untuk IHP adalah $2010(2010=100)$ berbeda dengan IHK dan SBH. Oleh karena itu, harga yang disepakati diambil dari IHK dan SBH yang ada datanya pada situs BPS, dengan asumsi bahwa harga tersebut adalah harga yang disepakati oleh konsumen dan produsen. Besarnya kenaikan 
harga produsen dari harga pada tahun dasar bisa didapat dari rumus Laspeyres sebagai berikut :

$$
\mathrm{L}_{01}=\frac{\sum_{i=1}^{n} p i 1 q i 0}{\sum_{i=1}^{n} p i 0 q i 0}=\mathrm{L}_{01}
$$

Contoh perhitungan kenaikan harga produsen dari harga tahun dasar berdasarkan IHP untuk pertanian, kehutanan, dan perikanan tahun 2014 :

Diketahui : IHP tahun 2014 adalah 127,04

$$
\begin{aligned}
2010 & =100 \\
\text { Jawab } & : \mathrm{P}_{2014}=\frac{127,04}{100}=1,27 \text { pi0 }
\end{aligned}
$$

Maka kenaikan harga produsen pada tahun 2014 dari harga tahun dasar yaitu sebesar 1,27. Harga tahun dasar dapat diambil dari Suvei Harga Produsen (SHP).

5) Setelah harga keseimbangan (Pe) dan kuantitas keseimbangan (Qe) didapatkan, maka langkah selanjutnya adalah menghitung area inefisiensi berdasarkan nilai pajak. Pertama, langkah yang harus dilakukan yaitu menentukan terlebih dahulu titik Pp atau harga produsen. Titik Pp bisa dihitung dengan cara sebagai berikut :

$$
\mathrm{Pp}=-\left(\frac{\text { Nilai Pajak }}{\mathrm{Qe}}\right)+\mathrm{Pe}
$$

Titik ini merupakan harga yang ditawarkan produsen sebelum adanya penambahan seperti pajak.

Contoh perhitungan titik Pp pertanian, kehutanan, dan perikanan tahun 2014 :

Diketahui : Nilai pajak tahun 2014 untuk pertanian, kehutanan, dan perikanan adalah 28.864

Kuantitas keseimbangan (Qe) adalah 70.308

Harga Keseimbangan (Pe) adalah 16,06

Jawab $\quad:$ Pp $=-\left(\frac{28.864}{70.308}\right)+16,06=15,65$

6) Untuk mengetahui jarak antara titik Pe ke titik Pp, maka bisa dihitung dengan cara mengurangkan kedua titik tersebut. Jarak antara kedua titik ini disimbolkan dengan huruf $\mathrm{x}$.

7) Secara logika yang menanggung beban pajak adalah produsen karena pajak yang dipungut oleh pemerintah dikenakan pada biaya produksi sehingga berpengaruh terhadap harga. Namun, ketika dilihat dalam kurva, tenyata selain mengurangi daerah surplus produsen, pajak juga akan mengurangi daerah surplus konsemen karena kuantitas berkurang dan harga naik. Maka dari itu, perlu dilakukan perhitungan untuk mencari harga konsumen setelah adanya pajak ( $\mathrm{Pk})$.

Titik Pk bisa didapat dengan cara menambahkan besarnya $\mathrm{x}$ dari titik Pe. Dalam hal ini jarak penambahan dari titik Pe ke titik Pk sama dengan jarak dari titik Pp ke titik Pe, maka pengurangan luas area surplus produsen akan sama dengan pengurangan luas area surplus konsumen.

Contoh perhitungan x dan $\mathrm{Pk}$ pertanian, kehutanan, dan perikanan tahun 2014:

Diketahui : $\mathrm{Pe}=16,06$

$$
\begin{aligned}
& P p=15,65 \\
\text { Jawab } & : \mathrm{x}=16,06-15,65=0,41 \\
& \mathrm{Pk}=16,06+0,41=16,47
\end{aligned}
$$

8) Diketahui bahwa harga dan kuantitas yang disepakati berada pada titik $\mathrm{E}$ atau equilibrium dan ketika ada penambahan pajak maka garis supply akan bergerak ke arah kiri yang menandakan bahwa adanya kenaikan harga dan pengurangan dalam kuantitas barang. Luas daerah segitiga yang terbentuk akibat adanya pajak inilah yang akan penulis hitung. Masing-masing titik segitiga inefisiensi ini diberi simbol huruf AEC. 
9) Untuk mencari tinggi segitiga AEC menggunakan asumsi bahwa garis supply dan demand berpotongan tegak lurus pada titik equilibrium, maka sudut pada titik $\mathrm{E}$ akan membentuk sudut $90^{\circ}$ atau sudut siku-siku. Maka menurut theorema geometri diasumsikan bahwa titik A membentuk sudut $45^{\circ}$ yang akan sama juga dengan titik $\mathrm{C}$ (titik $\mathrm{A}=$ titik $\mathrm{C}=45^{\circ}$ ). Dengan begitu segitiga yang terbentuk merupakan segitiga sama kaki.

10) Segitiga AEC ini dipotong menjadi dua bagian sama besar dengan sebuah garis yang dinamai dengan titik B, sehingga terbentuklah dua segitiga sama besar yaitu segitiga CEB dengan segitiga AEB. Untuk mencari garis $\overline{\mathrm{BE}}$, dihitung dengan cara tan 45 dikali dengan garis $\mathrm{x}$ yang merupakan selisih titik Pe dengan titik $\mathrm{Pp}$ atau titik $\mathrm{Pk}$ dengan titik Pe. Tinggi segitiga atau garis $\overline{\mathrm{BE}}$ juga digunakan untuk mengetahui besarnya pengurangan kuantitas yang diakibatkan adanya penambahan pajak.

Contoh perhitungan garis $\overline{\mathrm{BE}}$ pertanian, kehutanan, dan perikanan tahun 2014 :

Diketahui : Garis $\mathrm{x}=0,41$

Jawab : Garis $\overline{\mathrm{BE}}=\tan 45 \times 0,41=0,41$

11) Setelah mengetahui berapa besar harga keseimbangan, kuantitas keseimbangan, dan harga produsen, maka selanjutnya dapat dilakukan perhitungan nilai pajak dengan cara harga keseimbangan (Pe) dikali kuantitas keseimbangan (Qe) dikurangi harga produsen (Pp) dikali kuantitas keseimbangan (Qe), hasil dari perhitungan ini akan sama besarnya jika menghitung dengan cara harga konsumen $(\mathrm{Pk})$ dikali kuantitas keseimbangan (Qe) dikurangi harga keseimbangan (Pe) dikali kuantitas keseimbangan (Qe). Perhitungan ini dilakukan untuk membuktikan bahwa nilai pajak pada saat pertama perhitungan sama besarnya dengan nilai pajak yang ada pada kurva. Bila dituangkan dalam rumus adalah sebagai berikut:

$$
\text { Nilai pajak }=(\text { Pe } x \text { Qe })-(P p \times Q e)
$$

Contoh perhitungan nilai pajak pertanian, kehutanan, dan perikanan tahun 2014:

Diketahui : $\mathrm{Pe}=16,06$

$$
\begin{aligned}
& \mathrm{Pp}=15,65 \\
& \mathrm{Qe}=70.308
\end{aligned}
$$

Jawab $\quad$ : Nilai pajak $=(16,06 \times 70.308)-(15,65 \times 70.308)=28.864$

12) Berikut ini merupakan contoh ilustrasi kurva permintaan dan penawaran pada sektor lapangan usaha pertanian, kehutanan, dan perikanan tahun 2014 berdasarkan nilai pajak, menggunakan titik Pp, Pe, Pk, Qe, segitiga AEC, AEB, dan BEC, yang sudah dihitung sebelumnya :

Diketahui : Harga konsumen $(\mathrm{Pk})=16,47$

Harga keseimbangan $(\mathrm{Pe})=16,06$

Harga produsen $(\mathrm{Pp})=15,65$

Kuantitas keseimbangan $(\mathrm{Qe})=70.307,99$ dalam perhitungan dibulatkan 70.308 Kuantitas produksi (Qp) dan konsumsi $(\mathrm{Qk})=70.307,58$ 


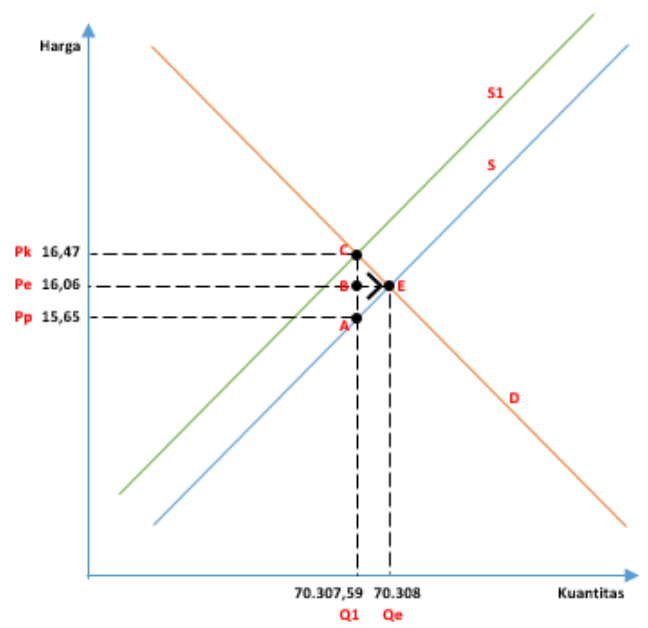

Gambar 3. Kurva Permintaan dan Penawaran Pajak

Sumber : Hasil Olahan Penulis

Dari gambar IV.2 diketahui bahwa beban produsen merupakan luas persegi panjang PeBAPp ditambah luas segitiga ABE, yang merupakan daerah pengurangan surplus produsen. Sedangkan, beban konsumen merupakan luas persegi panjang PkCBPe ditambah luas segitiga CBE, yang merupakan daerah pengurangan surplus konsumen. Sehingga penerimaan pajak bagi pemerintah sebesar luas daerah dari titik PkCAPp.

13) Langkah terakhir dan inti dari perhitungan yang ingin diketahui hasilnya adalah besar atau luas daerah segitiga inefisiensi berdasarkan nilai pajak. Hitungannya sama seperti mencari luas segitiga pada umumnya, yaitu $1 / 2$ dikali alas segitiga dikali juga dengan tinggi segitiga. Panjang alas bisa didapatkan dari panjang jarak antara $\mathrm{Pp}$ hingga $\mathrm{Pk}$ atau dihitung dengan cara mengurangkan $\mathrm{Pk}$ dengan $\mathrm{Pp}$ (hasil selisih), sedangkan tinggi segitiga sudah didapatkan sebelumnya dengan menghitungan garis $\overline{\mathrm{BE}}$.

Contoh perhitungan area inefisiensi berdasarkan nilai pajak pertanian, kehutanan, dan perikanan tahun 2014 :

Diketahui : $\mathrm{Pp}=15,65$

$$
\begin{aligned}
& \mathrm{Pk}=16,47 \\
& \mathrm{x}=0,41
\end{aligned}
$$

Garis $\overline{\mathrm{BE}}=0,41$ (tinggi segitiga)

Garis $\overline{\mathrm{AC}}=16,47-15,65=0,82$ atau Garis $\overline{\mathrm{AC}}=0,41 \times 2=0,82$ (alas segitiga)

Jawab $\quad:$ Luas segitiga $=1 / 2 \times 0,82 \times 0,41=0,168535$

Maka luas segitiga sebesar 0,168535 merupakan luas area inefisiensi yang timbul berdasarkan nilai pajak.

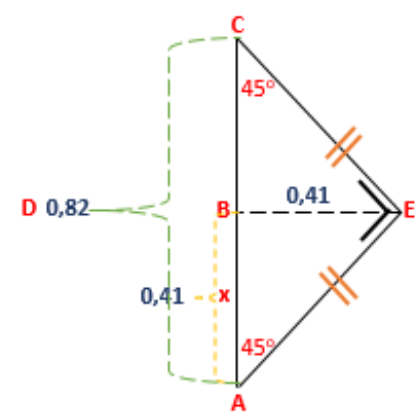

Gambar 4. Segitiga AEC Pajak

Sumber : Hasil Olahan Penulis 
Berikut langkah-langkah perhitungan area inefisiensi zakat:

1. Untuk menghitung area inefisiensi zakat, terlebih dahulu hal yang harus dilakukan yaitu menghitung besarnya harga keseimbangan yang terbentuk (Pe) dan harga yang akan dibayar konsumen (Pk). Berbeda dengan langkah-langkah menghitung area inefisiensi pajak, dalam hal ini titik mula sudah diketahui yaitu titik Pp. Seperti yang sudah dijelaskan sebelumnya, yang diasumsikan bahwa titik $\mathrm{Pp}$ atau harga produsen merupakan harga produksi yang belum mendapat penambahan apapun misalnya dalam bentuk zakat.

Contoh Pp (harga produsen) pada lapangan usaha pertanian, kehutanan, dan perikanan tahun 2014 adalah 15,65

2. Kemudian untuk menentukan nilai zakat, maka perhitungannya didasari oleh tarif zakat $2,5 \%$, terlepas dari jenis barang apa yang akan dizakatkan misalnya sawah tadah hujan dengan sawah irigasi, semua tarif disama ratakan karena dalam hal ini tidak ada data yang spesifik, baik mengenai tarif yang dikenakan bagi masing-masing sektor maupun besarnya penerimaan zakat dari masing-masing sektor. Maka tarif zakat 2,5\% ini digunakan juga untuk mengetahui berapa besarnya jarak penambahan dari titik Pp ke titik Pe atau bisa dihitung dengan cara Pp ditambah dengan 0,025. Masih dengan asumsi yang sama, dengan menyamakan jarak dari titik Pp ke titik Pe dengan jarak dari titik Pe ke titik Pk, maka titik Pk dihitung dengan cara Pe ditambah 0,025. Maka titik Pe (harga keseimbangan) pada lapangan usaha usaha pertanian, kehutanan, dan perikanan tahun 2014 berada pada 15,67 yang didapat dari 15,65 + 0,025 dan titik Pk (harga konsumen) berada pada 15,70 yang didapat dari 15,67 + 0,025. Asumsi yang digunakan untuk titik Pe yaitu harga yang disepakati di pasar sudah termasuk zakat.

3. Dalam perhitungan ini kuantitas keseimbangan atau Qe dianggap sama jumlahnya dengan Qe pada perhitungan pajak, karena data yang tersedia dan menjadi acuan dalam perhitungan adalah data dari produksi dari PDB.

Qe (kuantitas pada lapangan usaha pertanian, kehutanan, dan perikanan tahun 2014 adalah 70.308 .

4. Karena jarak dari titik Pp ke titik Pe sama dengan jarak dari titik Pe ke titik Pk yaitu 0,025, maka alas segitiga AEC adalah 0,05.

5. Sama seperti halnya perhitungan inefisiensi berdasarkan nilai pajak, untuk mencari tinggi segitiga AEC menggunakan asumsi bahwa garis supply dan demand berpotongan tegak lurus pada titik equilibrium, maka sudut pada titik $\mathrm{E}$ akan membentuk sudut $90^{\circ}$ atau sudut siku-siku. Maka menurut theorema geometri diasumsikan bahwa titik A membentuk sudut $45^{\circ}$ yang akan sama juga dengan titik $\mathrm{C}$ (titik $\mathrm{A}=$ titik $\mathrm{C}=45^{\circ}$ ). Dengan begitu segitiga yang terbentuk merupakan segitiga sama kaki.

6. Kemudian untuk menghitung tinggi segitiga atau garis $\overline{\mathrm{BE}}$ bisa diketahui dengan cara $\tan 45$ dikali dengan 0,025 yang merupakan garis x yaitu selisih titik Pe dengan titik Pp atau titik $\mathrm{Pk}$ dengan titik Pe. Tinggi segitiga atau garis $\overline{\mathrm{BE}}$ juga digunakan untuk mengetahui besarnya pengurangan kuantitas yang diakibatkan adanya penambahan zakat.

7. Setelah mengetahui berapa besar harga keseimbangan (Pe), kuantitas keseimbangan (Qe), dan harga produsen $(\mathrm{Pp})$, maka selanjutnya dapat mengitung nilai zakat dengan cara harga keseimbangan (Pe) dikali kuantitas keseimbangan (Qe) dikurangi harga produsen (Pp) dikali kuantitas keseimbangan (Qe), hasil dari perhitungan ini akan sama besarnya jika menghitung dengan cara harga konsumen $(\mathrm{Pk})$ dikali kuantitas keseimbangan (Qe) dikurangi harga keseimbangan (Pe) dikali kuantitas keseimbangan (Qe). Bila dituangkan dalam rumus adalah sebagai berikut :

$$
\text { Nilai zakat }=(\text { Pe } \times \text { Qe })-(\text { Pp } x \text { Qe })
$$

Contoh perhitungan area inefisiensi berdasarkan nilai zakat akan sama untuk seluruh lapangan usaha karena 2,5\% diterapkan pada semua sektor :

Diketahui : $\mathrm{Pe}=15,67$ 


$$
\begin{aligned}
& \mathrm{Pp}=15,65 \\
& \mathrm{Qe}=70.308
\end{aligned}
$$

Jawab : Nilai zakat $=(15,67 \times 70.308)-(15,65 \times 70.308)=1.758$

8. Langkah terakhir dan inti yang ingin diketahui hasilnya adalah besar atau luas daerah segitiga inefisiensi berdasarkan nilai zakat. Rumusnya yaitu $1 / 2$ dikali alas segitiga dikali juga dengan tinggi segitiga. Luas alas bisa didapatkan dari jarak antara Pp sampai Pk atau dihitung dengan cara mengurangkan $\mathrm{Pk}$ dengan $\mathrm{Pp}$ (hasil selisih), sedangkan tinggi segitiga sudah didapatkan sebelumnya dengan menghitungan garis $\overline{\mathrm{BE}}$.

Contoh perhitungan area inefisiensi berdasarkan nilai zakat untuk seluruh lapangan usaha, karena 2,5\% diterapkan pada semua sektor :

Diketahui : Garis $\overline{\mathrm{BE}}=\tan 45 \times 0,025=0,025$ (tinggi segitiga)

$$
\text { Garis } \overline{\mathrm{AC}}=15,70-15,65=0,05 \text { atau Garis } \overline{\mathrm{AC}}=0,025 \times 2=0,05 \text { (alas segitiga) }
$$

Jawab : Luas segitiga $=1 / 2 \times 0,05 \times 0,025=0,0006250$

Maka luas segitiga sebesar 0,0006250 merupakan luas area inefisiensi yang timbul berdasarkan nilai zakat.

9. Contoh gambar kurva permintaan dan penawaran pada lapangan usaha pertanian, kehutanan, dan perikanan tahun 2014 berdasarkan nilai zakat, menggunakan titik $\mathrm{Pp}, \mathrm{Pe}, \mathrm{Pk}, \mathrm{Qe}$, segitiga AEC, AEB, dan BEC, juga ilustrasi segitiga inefisiensi yang sudah dihitung sebelumnya :

Diketahui : Harga konsumen $(\mathrm{Pk})=15,70$

Harga keseimbangan $(\mathrm{Pe})=15,67$

Harga produsen $(\mathrm{Pp})=15,65$

Kuantitas keseimbangan $(\mathrm{Qe})=70.307,99$ dalam perhitungan dibulatkan 70.308 Kuantitas produksi (Qp) dan konsumsi (Qk) $=70.307,97$

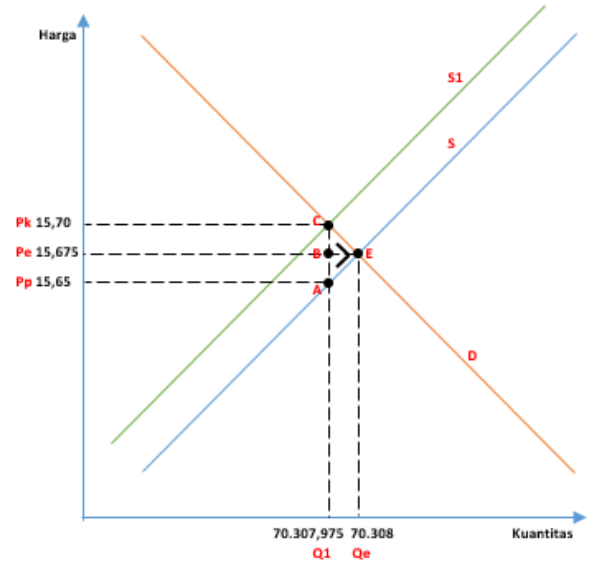

Gambar 5. Kurva Permintaan dan Penawaran Zakat Sumber : Hasil Olahan Penulis

Dari gambar IV.4 diketahui bahwa beban produsen merupakan luas persegi panjang PeBAPp ditambah luas segitiga ABE, yang merupakan daerah pengurangan surplus produsen. Sedangkan, beban konsumen merupakan luas persegi panjang PkCBPe ditambah luas segitiga CBE, yang merupakan daerah pengurangan surplus konsumen. Sehingga penerimaan pajak bagi pemerintah sebesar luas daerah dari titik PkCAPp. 


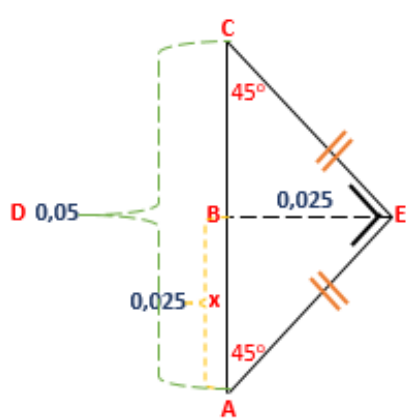

Gambar 6. Segitiga AEC Zakat

Sumber : Hasil Olahan Penulis

\subsection{Pengujian Hipotesis}

Pengujian hipotesis pertama-tama melakukan uji normalitas data, jika data berdistribusi normal maka melakukan uji beda dua sampel independen, namun jika data tidak berdistribusi normal maka dilakukan uji beda non-parametrik Mann-Whitney Test, dan alternatif pengujian lainnya seperti, Moses Test, Two Sample Kolmogorov-Smirnov Test, dan Wald- Wolfowitz, Test.

\section{Uji Normalitas}

Uji normalitas dilakukan untuk mengetahui data yang dianalisis berdistribusi normal atau tidak. Pada penelitian ini, uji normalitas dilakukan dengan melihat hasil dari Shapiro Wilk.

Tabel 3. Pengujian Normalitas

\begin{tabular}{|r|r|r|r|r|r|r|r|}
\hline \multirow{2}{*}{} & \multirow{3}{*}{ Nests of Normalityc } \\
\cline { 3 - 9 } & Nilai & \multicolumn{2}{|c|}{ Kolmogorov-Smirnov } & \multicolumn{3}{c|}{ Shapiro-Wilk } \\
\cline { 3 - 9 } & Statistic & \multicolumn{1}{c|}{ df } & Sig. & Statistic & \multicolumn{1}{c|}{ df } & Sig. \\
\hline Inefisiensi & Pajak &, 102 & 25 &, $200^{\circ}$ &, 937 & 25 &, 127 \\
\hline
\end{tabular}

*. This is a lower bound of the true significance.

a. Lilliefors Significance Correction

c. Inefisiensi is constant when Nilai = Zakat. It has been omitted.

Sumber: Output SPSS 23

Berdasarkan tabel output di atas diketahui nilai df (derajat kebebasan) untuk inefisiensi nilai pajak adalah 25, pada keterangan dijelaskan bahwa inefisiensi nilai zakat hasilnya adalah konstan, maka dari itu hasilnya tidak ditampilkan. Hasil dari uji normalitas Shapiro-Wilk yaitu data berdistribusi normal dilihat dari nilai signifikansi sebesar 0,127 ( $p>0.05)$, maka dari itu pengujian hipotesis untuk membandingkan antara inefisiensi pajak dengan inefisiensi zakat menggunakan independent sample t-test.

\section{Independent Sample T-Test}

Hasil dari uji normalitas menunjukkan bahwa data berdistribusi normal, maka dilakukan independent sample t-test. Berikut hasil dari pengujian yang dilakukan:

Tabel 4. Statistik Deskriptif

\begin{tabular}{|ll|l|c|r|r|}
\hline \multicolumn{1}{|c|}{} & Nilai & N & Mean & Std. Deviation & Std. Error Mean \\
\hline \multirow{2}{*}{ Inefisiensi } & Pajak & 25 &, 4220335832 &, 2862147540 &, 0572429508 \\
& Zakat & 25 &, 0006250000 &, 0000000000 &, 0000000000 \\
\hline
\end{tabular}

Sumber : Output SPSS 23 
Berdasarkan tabel output "Group Statistics" di atas diketahui jumlah data inefisiensi nilai pajak adalah 25, begitu juga jumlah data inefisiensi nilai zakat sebanyak 25. Nilai rata-rata inefisiensi atau Mean untuk nilai pajak adalah 0,4220335832, sementara untuk nilai zakat sebesar 0,0006250000. Dengan demikian secara deskriptif statistik dapat disimpulkan bahwa terdapat perbedaan rata-rata area inefisiensi antara nilai pajak dengan nilai zakat. Kemudian untuk membuktikan apakah perbedaan tersebut signifikan atau tidak, maka dilakukan penafsiran output "Independent Sample TTest" sebagai berikut :

Tabel 5. Pengujian Independent Sample T-Test

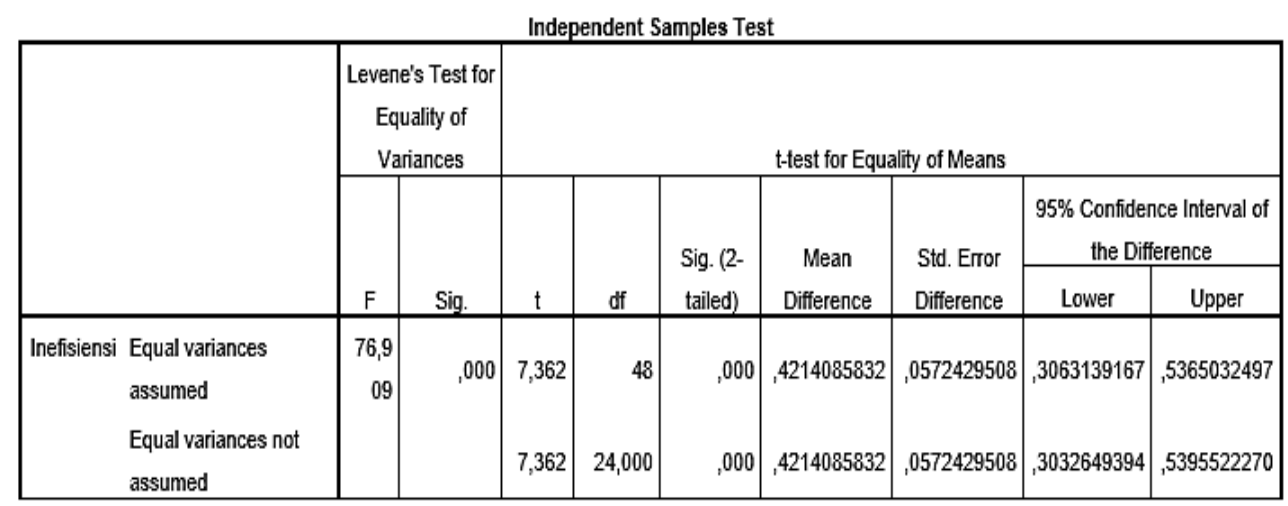

Sumber : Output SPSS 23

Berdasarkan output di atas pada kolom Levene's Test for Equality of V ariances, taraf Sig. F adalah 0,000, maka dapat diartikan bahwa kedua varians populasi tidak identik, sehingga t-test yang dilakukan berpedoman pada hasil yang terdapat pada Equal V ariances Not Assumed. Pada bagian “Equal Variances Not Assumed" diketahui nilai Sig (2-tailed) sebesar 0,000<0,05, maka sebagaimana dasar pengambilan keputusan dalam independent sample t-test, disimpulkan bahwa $\mathrm{H}_{0}$ ditolak dan $\mathrm{H}_{1}$ diterima, yaitu terdapat perbedaan yang signifikan antara daerah inefisiensi nilai pajak dengan nilai zakat.

Selanjutnya, dari tabel output di atas diketahui "Mean Differences" adalah 0,4214085832, nilai ini menunjukkan selisih antara rata-rata inefisiensi nilai pajak dengan rata-rata inefisiensi nilai zakat yaitu $0,4220335832-0,0006250000=0,4214085832$ dan selisih untuk perbedaan tersebut adalah 0,3032649394 sampai 0,5395522270 (95\% Confidence Interval of the Difference Lower Upper).

\subsection{Pembahasan Hasil Penelitian}

Pada bagian ini akan dibahas secara lebih jelas dan lebih rinci mengenai hasil perhitungan dan pengujian hipotesis yang telah dilakukan. Berikut penjelasannya:

Dari analisis yang telah dilakukan, dapat diketahui bahwa terdapat perbedaan yang signifikan antara area inefisiensi berdasarkan nilai pajak dengan nilai zakat. Ketika besarnya nilai pajak dan nilai zakat sudah diketahui, kemudian hasilnya dibandingkan secara langsung berdasarkan perhitungan kuantitatif, maka didapatkan hasil dimana nilai pajak jauh lebih besar dibandingkan nilai zakat. Hasil dari besarnya nilai pajak dan nilai zakat juga berpengaruh kepada area inefisiensi. Hasil perbandingan berdasarkan perhitungan kuantitatif antara NIP (Nilai Inefisiensi Pajak) dengan NIZ (Nilai Inefisiensi Zakat) menunjukkan bahwa NIP jauh lebih besar dibandingkan NIZ. NIZ hasilnya mendekati nol $(0,0)$, sehingga dapat dibuktikan bahwa area inefisiensi berdasarkan nilai zakat kecil kemungkinan untuk mempunyai area inefisiensi yang lebih besar daripada area inefisiensi yang ditimbulkan oleh nilai pajak. Berikut hasil perbandingan antara nilai pajak dengan nilai zakat dan NIP dengan NIZ:

Tabel 1. Hasil Perhitungan Kuantitatif Nilai Pajak, Nilai Zakat, NIP, dan NIZ 


\begin{tabular}{|c|c|c|c|c|}
\hline Sektor & Nilai Pajak & Nilai Zakat & NIP & $\mathrm{NIZ}$ \\
\hline 42014 & 28.864 & 1.758 & 0,1685 & 0,0006 \\
\hline A. 2015 & 38.105 & 1.715 & 0,3087 & 0,0006 \\
\hline 42016 & 44.845 & 1.712 & 0,4288 & 0,0006 \\
\hline A 2017 & 50.391 & 1.581 & 0,6346 & 0,0006 \\
\hline 42018 & 55.166 & 1.576 & 0,7654 & 0,0006 \\
\hline 32014 & 47.403 & 7.183 & 0,0272 & 0,0006 \\
\hline 32015 & 62.927 & 7.166 & 0,0482 & 0,0006 \\
\hline 32016 & 74.691 & 7.239 & 0,0665 & 0,0006 \\
\hline 32017 & 84.266 & 7.658 & 0,0757 & 0,0006 \\
\hline 32018 & 92.571 & 7.699 & 0,0904 & 0,0006 \\
\hline C2014 & 2.412 & 119 & 0,2579 & 0,0006 \\
\hline C2015 & 3.097 & 111 & 0,4898 & 0,0006 \\
\hline $\mathrm{C} 2016$ & 3.986 & 114 & 0,7628 & 0,0006 \\
\hline $\mathrm{C}_{2017}$ & 4.082 & 119 & 0,7343 & 0,0006 \\
\hline $\mathrm{C} 2018$ & 4.876 & 132 & 0,8588 & 0,0006 \\
\hline 2014 & 8.358 & 401 & 0,2710 & 0,0006 \\
\hline 2015 & 11.348 & 403 & 0,4963 & 0,0006 \\
\hline 2016 & 13.882 & 435 & 0,6366 & 0,0006 \\
\hline 2017 & 16.292 & 452 & 0,8116 & 0,0006 \\
\hline 2018 & 18.368 & 475 & 0,9357 & 0,0006 \\
\hline 2014 & 6.591 & 468 & 0,1242 & 0,0006 \\
\hline 2015 & 8.748 & 455 & 0,2311 & 0,0006 \\
\hline 2016 & 10.474 & 453 & 0,3348 & 0,0006 \\
\hline 2017 & 11.941 & 445 & 0,4505 & 0,0006 \\
\hline 2018 & 13.293 & 452 & 0,5415 & 0,0006 \\
\hline
\end{tabular}

Sumber : Hasil Olahan Penulis

Untuk mempersingkat penulisan, maka setiap lapangan usaha diberikan huruf sebagai simbol seperti sektor A untuk pertanian, kehutanan, dan perikanan, sektor B untuk industri pengolahan, sektor C untuk listrik, gas, dan air, sektor D untuk transportasi dan pergudangan, sektor E untuk penyediaan akomodasi, makanan, dan minuman.

Ketika melakukan independent sample t-test, didapatkan hasil bahwa nilai signifikansi $<0,05$, artinya " $\mathrm{H}_{0}$ ditolak" dan " $\mathrm{H}_{1}$ diterima" yaitu terdapat perbedaan yang signifikan antara daerah inefisiensi nilai pajak dan nilai zakat. Hasil perhitungan kuantitatif dan pengujian hipotesis ini memperkuat penelitian dari M Nur Rianto Al Arif (2011), Mohammed B. Yusoff (2010), Hisham H. Abdelbak (2014), Dwi Retno Widiyanti (2016), bahwa zakat merupakan istrumen fiskal yang dapat meningkatkan kinerja perekonomian karena tidak akan menimbulkan area inefisiensi atau minimal menghasilkan area inefisiensi yang jauh lebih kecil dibandingkan pajak, sehingga pemerataan pendapatan dapat dicapai.

Dalam hal ini pengurangan surplus konsumen dan surplus produsen akibat penambahan zakat tidak akan terlalu besar dibandingkan dengan pajak, dapat dibuktikan dengan penjelasan pada situs BPS yaitu pajak tidak langsung yang dibebankan pemerintah akan dikenakan pada biaya produksi sehinga akan berpengaruh pada harga. Perlu diketahui bahwa dengan adanya pajak, maka kuantitas barang atau jasa akan berkurang dan harga akan semakin tinggi, hal itulah yang menyebabkan daerah inefisiensi pajak jauh lebih besar daripada inefisiensi zakat. Secara teori dijelaskan bahwa semakin besar tarif pajak maka semakin besar pengurangan surplus produsen dan surplus konsumen sehingga semakin besar pula daerah inefisiensi yang ditimbulkan, sedangkan tarif zakat untuk perindustrian hanya sebesar 2,5\% seperti yang diterangkan dalam Peraturan Menteri Agama No. 52 Tahun 2014 dan besarnya tarif zakat tidak akan berubah karena sudah mutlak ketetapan Allah.

Pembuktian selanjutnya dapat dihitung menggunakan koefisien elastisitas dengan rumus $\frac{\Delta \mathrm{Q}}{\Delta \mathrm{P}} \times \frac{\mathrm{P}}{\mathrm{Q}}$. Contoh perhitungan untuk sektor lapangan usaha pertanian, kehutanan, dan perikanan 
tahun 2014 berdasarkan nilai pajak menghasilkan nilai koefisien elastisitas permintaan (Ed) sebesar $-0,00022842$, artinya perubahan harga sebanyak $1 \%$ menyebabkan perubahan permintaan sebanyak $0,00022842 \%$ dan nilai koefisien elastisitas penawarannya (Es) adalah 0,00022842. Sedangkan untuk sektor lapangan usaha pertanian, kehutanan, dan perikanan tahun 2014 berdasarkan nilai zakat menghasilkan nilai koefisien elastisitas permintaan (Ed) sebesar -0,0002229, artinya perubahan harga sebanyak 1\% menyebabkan perubahan permintaan sebanyak $0,0002229 \%$ dan nilai koefisien elastisitas penawarannya (Es) adalah 0,0002229. Koefisien elastisitas dilakukan untuk mengetahui perubahan harga terhadap besar kecilnya perubahan jumlah barang yang diminta atau ditawarkan, semakin besar nilai elastisitas (E), semakin elastis permintaan dan penawarannya, karena perubahan permintaan dan penawaran jauh lebih besar dibanding perubahan harga. Dari hasil perhitungan koefisiensi elastisitas dapat diketahui bahwa perubahan harga yang disebabkan oleh pajak akan menghasilkan perubahan permintaan dan penawaran yang lebih besar dibandingkan dengan perubahan harga yang disebabkan oleh zakat, hal ini berpengaruh pada area inefisiensi yang ditimbulkan yaitu area inefisiensi berdasarkan nilai pajak lebih besar daripada area inefisiensi berdasarkan nilai zakat.

Dari pembahasan dan beberapa pembuktian yang sudah dilakukan, dapat disimpulkan bahwa seluruh elemen, baik konsumen, produsen, maupun pemerintah akan terpenuhi kesejahteraannya, konsumen akan lebih termotivasi untuk memenuhi kebutuhan, produsen dapat meningkatkan produksinya karena lebih efisien dalam hal biaya, pemerintah juga dapat menyerap dana secara optimal karena area deadweight loss sangat kecil sehingga dapat dialokasikan pada delapan asnaf dan apabila sudah terpenuhi maka digunakan untuk pembangunan serta pengembangan negara demi kesejahteraan masyarakat sehingga lebih bermanfaat, dan yang paling penting yaitu para pelaku di dalamnya akan mendapatkan keberkahan.

\section{Penutup}

Kesimpulan dalam penelitian ini yaitu, terdapat perbedaan yang signifikan antara daerah inefisiensi nilai pajak dan nilai zakat. Dari sisi akademik telah dibuktikan bahwa kebijakan pajak menimbulkan daerah inefisiensi yang besar, semakin besar penerimaan pajak maka semakin besar pula daerah inefisiensi. Sedangkan zakat yang merupakan alat redistribusi dalam Islam menghasilkan daerah inefisiensi yang jauh lebih kecil dibandingkan pajak bahkan hasilnya bisa mendekati nol. Jika dana zakat dioptimalkan maka tidak menutup kemungkinan daerah inefisiensi akan berubah menjadi efisiensi, itu artinya kesejahteraan konsumen, produsen, dan pemerintah akan tercapai.

Diharapkan penelitian ini dapat membuka peluang bagi peneliti lain untuk mengembangkan penelitian yang serupa dengan masalah yang sama, karena penelitian ini membutuhkan inovasiinovasi baru, baik dalam penggunaan rumus, pemilihan data yang mudah didapatkan pada situs resmi seperti Badan Pusat Statistik, dan sebagainya. Karena menurut peneliti, penelitian ini perlu dikembangkan dari sisi akademik, sehingga masyarakat atau pihak lain yang bersangkutan dapat mudah mengerti ketika membaca dan hasilnya dapat diterima secara logika.

\section{Daftar Pustaka}

Abdelbaki, H. (2014). Assessment the Impact of Zakat on Aggregate Consumption and Poverty: Evidence From Egypt. British Journal of Economics, Management \& Trade, 1306-1322.

Al Arif, M. R. (2013). Fungsionalisasi Zakat dan Pajak di Dalam Perekonomian. Jurnal Ekonomi Islam, 3, 35-62.

Al Arif, M. R. Efek Multiplier Zakat Terhadap Pendapatan Di Provinsi Dki Jakarta. Ikatan Ahli Ekonomi Islam Indonesia (IAEI): Tugas Akhir Tidak Diterbitkan. 2011. 
Beik, I. S. (2009). Analisis Peran Zakat dalam Mengurangi Kemiskinan : Studi Kasus Dompet Dhuafa Republika. Jurnal Pemikiran dan Gagasan, 2.

Cahyono, A. T., \& Putri, E. E. (2012). Penerapan Zakat Sebagai Perencanaa Pajak untuk Efisiensi PPh Badan pada PT Alwan Zahira Samarinda. Jurnal Eksis, 7.

Galang, K. (2017). Deadweight Loss. Dipetik 17 Juni 2019, dari WordPress.com: www.google.com/amp/s/kageweblog.wordpress.com/2017/08/4/deadweightloss $/ \mathrm{amp} /$ ?espv $=1$.

Iman, E.A., Setyowati, D.H., \& Setiawan, S. (2018). Penurunan Persentase Kemiskinan Sebagai Dampak Kinerja Keuangan Organisasi Pengelola Zakat di Indonesia. Prosiding Industrial Research Workshop and National Seminar 9, 728-736

Karim, A. A. (2007). Ekonomi Mikro Islami. Depok: PT RajaGrafindo Persada.

Majalah Indonesia Tax Review. (2013). Pajak Penghasilan dan Distorsi yang Diakibatkannya, Suatu Pemikiran dari Perspektif Ekonomi. Jakarta Selatan: SMARTaxes Publishing.

Musonnif, A., \& Asiyah, B. N. (2012). Teori Perubahan Situasi (Nazhariyat Al-Zhuruf Al-Thari'ah) Dalam Perspektif Hukum Ekonomi Islam. Epistemé, 7, 412.

Reza, H. (2012). Mengangkat Nilai "Zakat dengan Hati" : Refleksi Fenomenologis Zakat Perusahaan Pengusaha Arab. Jurnal Akuntansi Mularadigma (JAMAL), 1-160.

Suryana. (2010). Metodologi Penelitian. Dipetik 14 Oktober 2018, dari https://www.academia.edu/8944806/Ebook_metode_penelitian?auto=download.

Widiyanti, D. R. (2016). Partial Equilibrium Analysis on Zakat. 30. Diambil kembali dari https://www.researchgate.net/profile/Dwi_Retno_Widiyanti.

Yusoff, M. (2010). An Analysis Of Zakót Expenditure And Real Output: Theory And Evidence. IIUM Journal of Economics and Management, 139-60. 